\title{
林床環境の時空間変動 一とくに光環境に注目して一
}

\section{1.はじめに}

環境問題を解明するために，ある地域や流域単位 の現象を総括的かつ定量的に捉える必要性が頻繁に 生じている。例えば気候変動枠組条約締約国会合 (COP) でも，森林の二酸化炭素固定能がどれだけ あるかが会議の大きな論点になった。 しかし, 森林 や草原のような「自然」に近い生態系は, 農地や都 市といった「人為」の影響を強く受けた生態系と較 べて，より不均一性が高いと思われる. 近年の計測 技術の進歩のおかげで，ある地点のある時刻の值を 正確に計測することはできるようになったが，それ が果たして森林を代表しているといえるだろうか. リモートセンシングは広域情報を同一のセンサで一 瞬のうちに取得できる有力な道具ではあるが，万能 ではない．現地における詳細な計測值と広域的なり モートセンシング情報, さらにこの二つをつなぐモ デルが重要な役目を果たすように思われる. そのモ デルの初期值やパラメータをどう決めるかが推定の 精度を決定づけるといっても過言ではない.

このように不均一な環境条件下で広域にわたる現 象を総括的かつ定量的に捉えたり，あるいは現状を 把握した上で, 過去の推定から将来の予測につなげ るにはどうしたらよいか，いまその手法開発が求め られている. 換言するなら, 情報の時 - 空間的拡大 は環境科学を扱う研究者にとって普遍的・根元的な 問題である.

そこで我々は，実際の森林内のいろいろな環境因 子，とくに光が面的にどのような変異をもって分布 しているのか, それが季節的にどのように変動して いるかを詳しく調べている，また，その結果を今後 どのような研究につなげていくかを検討しているの で報告する。

\section{2. 試験林の概況}

対象とする試験林は，岐阜県高山市と丹生川村の 境界（北緯 $36^{\circ} 08^{\prime}$ ，東経 $137^{\circ} 25^{\prime}$ ）に位置する。乗鞍 岳の南西斜面上にあり，標高はほぼ $1400 \mathrm{~m}$ の落葉 広葉樹林である。ここに 1 ha $(100 \mathrm{~m} \times 100 \mathrm{~m})$ の 試験林を設け，中を $10 \mathrm{~m} \times 10 \mathrm{~m}$ の小試験区100区に 分割し，1997年から詳細な調査を実施している．林 床の光環境に関わる要因について以下に概説する。

\section{1 気象，地形と標高}

当地は冷温带に属し, 年平均気温は $7.2^{\circ} \mathrm{C}$, 年降 水量は $2,382 \mathrm{~mm}$ で, 冬季の最大積雪深は $1 \mathrm{~m}$ を超え る. 太平洋側気候と日本海側気候の両方の影響を受 ける地域といえる。

図一 1 に対象となる試験林の地形を示した. 南北 に尾根があり，その間を西側に開けた谷が走ってい る. 最高点が $1428 \mathrm{~m}$, 最低点が $1392 \mathrm{~m}$ である. 100 区の小試験区のうち, 頂部が 30 , 谷部が 19 , 北斜 面が 25 , 南斜面が 19 , 西斜面が 7 箇所と区分され た。

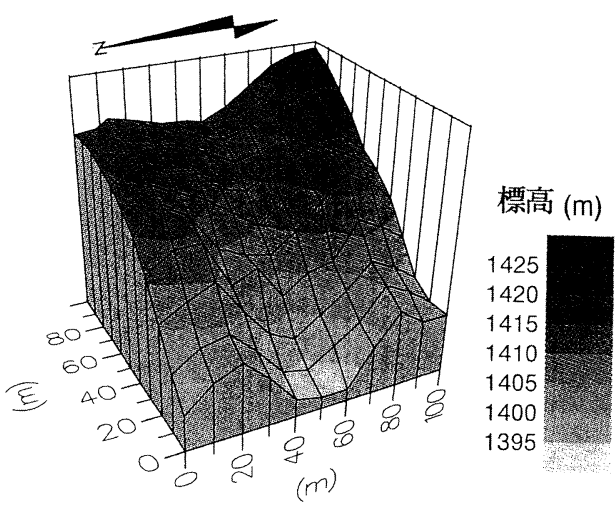

図－1 試験林地形図 


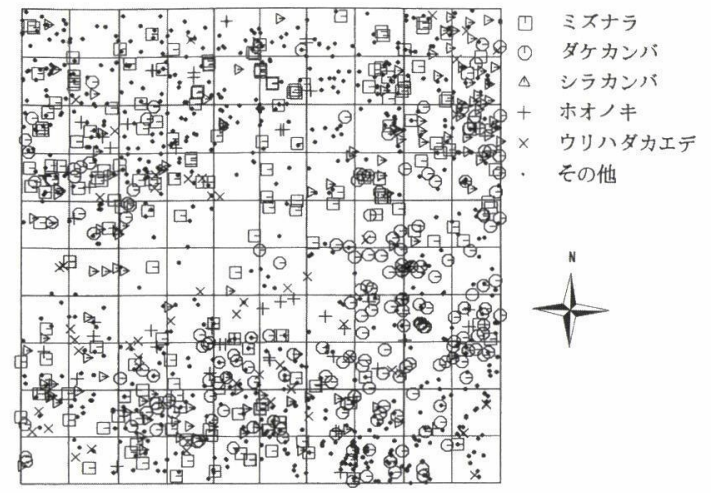

図-2 試験林内の全樹木の分布図 （上位 5 種およびその他）流域環境研究センター作成

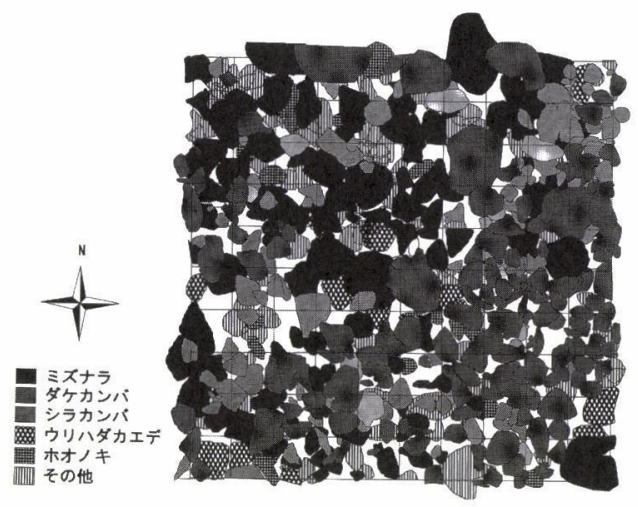

図－３＼cjkstart試験林の樹冠投影図（川村方，2000）

\section{2 植 生}

試験林内のすべての樹木の樹種，位置，胸高直径 （DBH，地上 $120 \mathrm{~cm} に お け る$ 幹の太さ）などを登録 した。このような樹木の戸籍調べを「毎木調査」と いう。これによって胸高直径から樹木の乾物重を推 定できる。また間隔を置いて毎木調査を実施するこ とにより，その間の樹木の生長量や炭素固定量を推 定することもできる.

現在, 1 haの試験区には胸高直径が $2 \mathrm{~cm}$ 以上の 樹木が 1,835 本生育している。胸高直径による相対 生長式で推定した樹木地上部の総乾物重は $154 \mathrm{t} / \mathrm{ha}$ であった (秋山ら ${ }^{1)}$ )。また，この森で最も優占する 樹木はミズナラ (27\%) で，ついでダケカンバ (25 \%), シラカンバ (15\%) の順であった（カッコ内 は重量割合を示す).上位 5 樹種の分布図を図一2 に示した，明らかに分布の偏りが認められ，南東部 分にカンバ類が，北西部分にミズナラが多い.

図ー3は樹冠投影図と呼ばれる図で，空から見た
森林の投影図にほぼ相当する。白く抜けた部分が ギャップと呼ばれる隙間で, ここを通して直達光が 森林の林床に到達する。川村ら ${ }^{21}$ の観察によると， 調査林の落葉広葉樹の開葉はオオカメノキなどの林 床植生が最も早く 4 月中旬から, 次いでカンバ類が 4 月末から芽が動く、ミズナラはさらに 1 週間ほど 遅いが, 落葉も2 週間ほど遅い。開葉, 落葉につい ては年次的な变異も大きいようだ。

\section{3. 光の計測法}

\section{1 フィルム式簡易積算日射計}

試験林が落葉広葉樹に覆われているため，葉の展 開や落葉などの葉群動態 (leaf phenology) に伴い, 林床の光環境は季節的に変化する．また，同じ日の 同じ時刻であっても, ギャップの存在や樹冠を覆っ ている樹種の違いから, 林内の光条件は場所によっ ても大きく異なることが予想される。これを測るに は多点の光を安価に計測できる測器が必要である。 フィルム式簡易積算日射計（以後フィルム日射計と 省略）のフィルム部分は千葉大学と大成化工（株） が数年前に共同開発し，現在はオプトリーフの商品

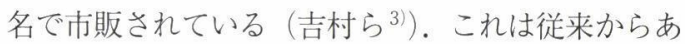
るジアゾ感光紙を改良した特殊なフィルムで，これ をスライドマウントに挟み現地に設置し数日間露光 させ，フィルムの退色程度からその間の積算日射量 を推定する。

フィルム日射計は手作りである。また，フィルム の退色は化学反応であることから, 温度に依存する. そのため広い温度域のもとで検量線を作る必要があ る.ささらに野外での検証実験例が少なかったので, 正確に利用できる条件（日数や気象等）についても 検討した。このようなフィルム日射計の作り方から 検量線作成，感度と精度の確認，適用範囲の検討な どの詳細については，前報4を参照されたい．

図一 4 はネオ全天日射計（英弘精機製MS-42型） で計測した日射量とフィルム日射計による測定值を 比較した図である。フィルムにはOR-O（商品名R2D）とPAN (Y-1W) の 2 種類があり, 前者は積 算日射量が $100 \sim 150 \mathrm{MJ} / \mathrm{m}^{2}$, 後者が $200 \mathrm{MJ} / \mathrm{m}^{2}$ 程度 までは直線性が維持されるが，ここではOR-Oの結 果のみを示した。

\section{2 林内における計測}

我々の試験林では縦横 $10 \mathrm{~m} こ ゙ と （ 121$ 箇所）に高 さ150 cmのポールを立て，そこで林内の日射量（Ia） 


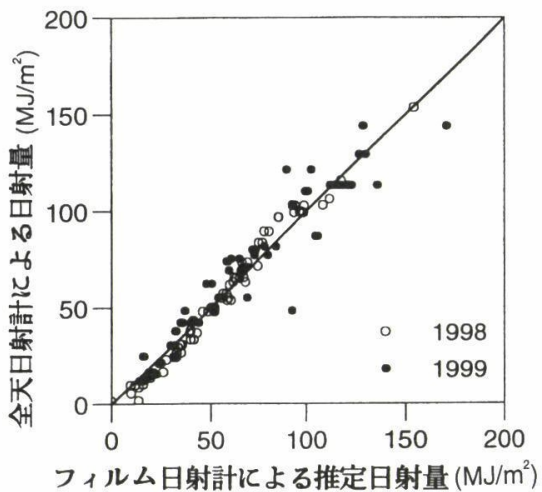

図－4 フィルム日射計（OR-O）と全天日射計による 積算日射量の比較 (秋山4 $)$

を測定した。高さを $150 \mathrm{~cm}$ としたのは，林床が高さ $1 \mathrm{~m}$ 程度のクマイザサに覆われているためである. ポールの根元，地表約 $10 \mathrm{~cm}$ 場所でも同様に日射 量（Ib）を测是した。こうすることにより，Io-Ia で樹木層が吸収する日射量（ここでIoは林冠上の日 射量とする）と，Ia-Ibでササ層が吸収する日射量 とを分離して推定できるからである。この方法を用 いて，1998年と1999年の開葉前から落葉後までの あいだ約 2 週間の間隔で林内の242点, (121地点X 2 階層) の積算日射量を求めた。林内における測定 の様子を写真 1 に示した。

\section{4. 林内光環境の時空間変化}

図ー5は林内の光環境の面的な分布状態を季節別
に示している，この図は林外の光に対する相対割合 (Ia/Io, Ib/Io）で表示されているが，絶対值（MJ/ $\mathrm{m}^{2} /$ day）でも示すことができる．春や秋の落葉期 間には Ia/Ioの場所による変動が大きいが，春と秋 の日射量分布のパターンは類似している，完全に林 冠が閉鎖される夏の期間は場所による差が縮まる.

一方，季節的な変動を図ー6に示した，上が絶対 值表示で，林外の日射量も表示してある．図は1998 年の例を示しているが, この年は 3 月 31 日から 12 月 1 日まで17期間にわたって継続して測定し，図の 各点は121箇所の平均值である。この図から落葉広 葉樹林の林床 $(\mathrm{Ia}, 150 \mathrm{~cm})$ は葉のない季節でも外 光の半分程度であることが判る。これは枝による遮 光の影響が大きいが，太陽高度が低い季節（特に晚 秋）には北斜面が山陰に入ってしまうことも影響し ている. Iaは無葉期には10MJ，樹木の葉がある季 節には $3 \mathrm{MJ}$ 程度になる。一方, Ib $(10 \mathrm{~cm})$ は 1 年 中 $3 \mathrm{MJ}$ を超える季節がなく, ギャップがなければ 樹木の実生苗が育つことは困難である.

図ー6の下は相対值である. 春と秋には0.5 (50\%) 以上であった相対日射量（Ia/Io）は急激に低下し， 夏の間は 0.1 程度となり，秋には落葉につれて再び 明るくなった。これに対して $\mathrm{Ib} / \mathrm{Io}$ は春秋に $0.2 を$ えるが，夏の間は 0.05 以下であった。

\section{5 . 今後の展開}

今回は林内の光に関わるデータのみを示したが,

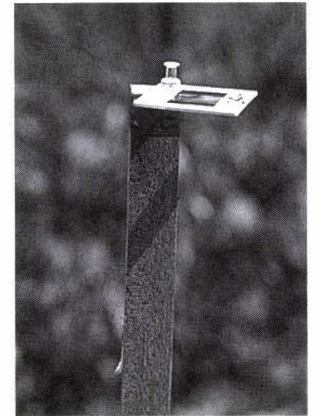

写真 1 ポール上に設置され たフィルム日射計
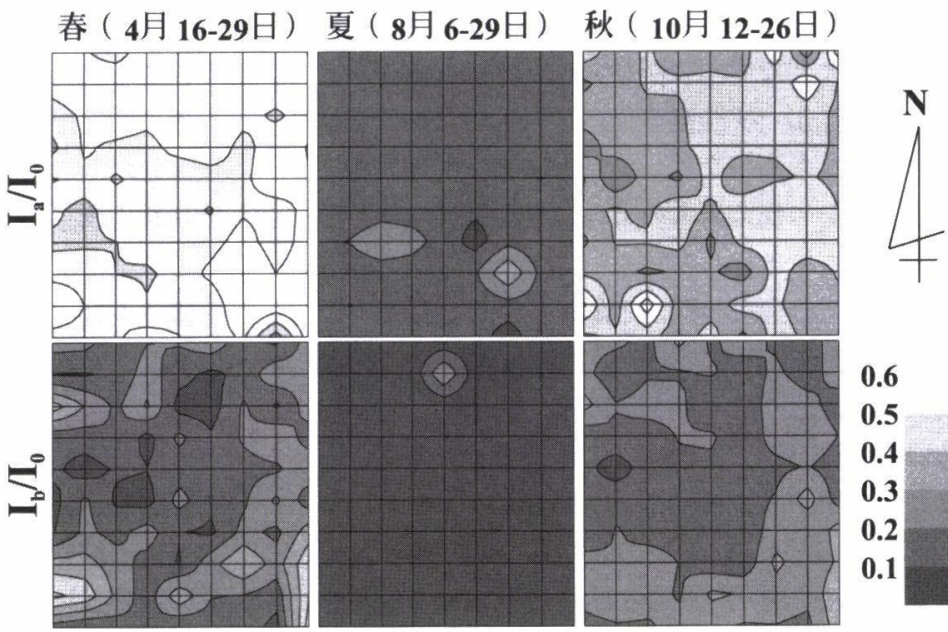

図一 5 季節別にみた試験林内の光環境の面的変動

図は林冠上日射量（Io）に対する林床植生上部（Ia 上図）と，林床植生下部（Ib下図）の 相対值で示した（1998年） 


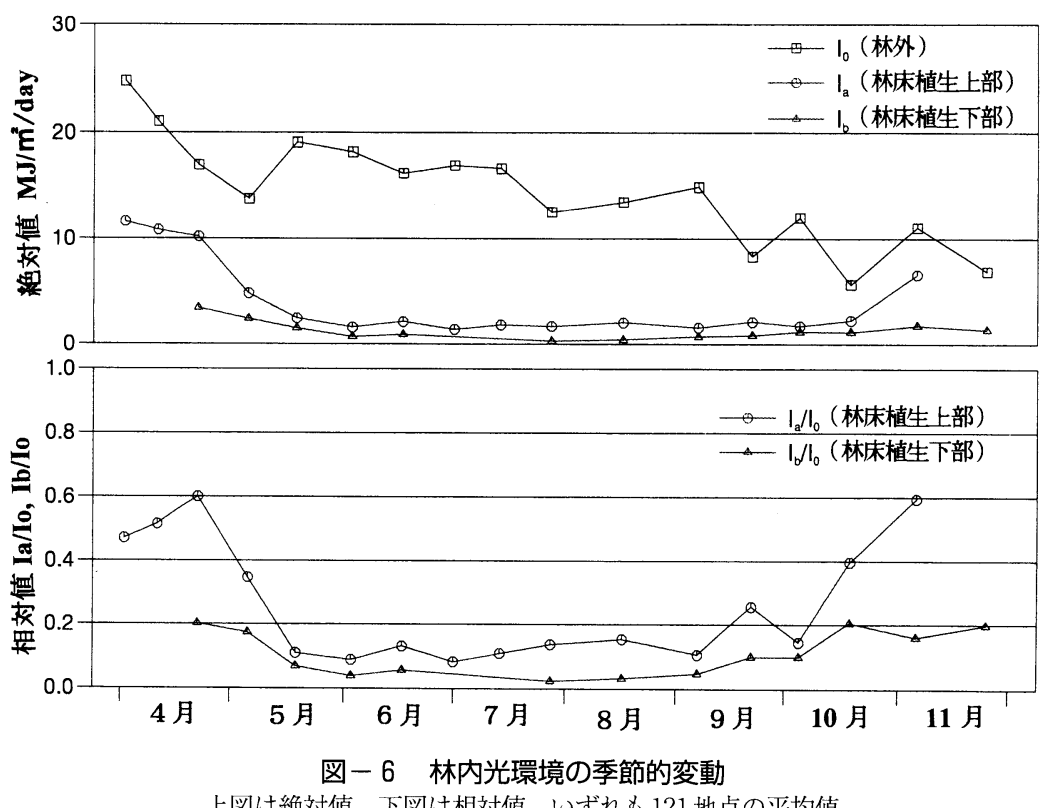

上図は絶対値, 下図は相対值, いずれも 121 地点の平均值

現在試験林では次のような項目についても同じ 100 の小試験区ごとに季節を追って測られている.

気象関係; 気温（地表と地上 $1 \mathrm{~m}$ )

土潩関係; 土壤の物理性・化学性, 土壤発達構造 (2 m深まで), リ夕ー厚, リ夕一重, 土壊水分 (10 $\mathrm{cm}$ 深), 土壤呼吸量, 土壤中 $\mathrm{CN}$ 量分布

植生関係; 樹木生長量, ササバイオマス分布

このような 100 地点の実測の光デー夕を使って森 林やササ群落における二酸化炭素の季節的な動態を 計算しょうと試みている，同じ地点で経済産業省の 資源環境技術総合研究所が1993年以降, $27 \mathrm{~m}$ の観 測タワーを建て, 二酸化炭素, 気温, 湿度, 日射量, 風向・風速を通年観測を行って，フラックスから毎 日の二酸化炭素交換量を求めている ${ }^{5)}$ ので，二つの 異なる方法による森林の炭素動態の比較が可能にな る.

また，川村ら ${ }^{2)}$ は樹木葉の展開・落葉の時期を観 察し，これと樹冠投影図とを組み合わせて，林内の 光環境と樹種の関係を解析している. その結果, 春 や秋には上にある樹種によって明るさに違いが生じ ることが認められている.

このほか, 賈ら ${ }^{6}$ は土壤圈における炭素の動態を 明らかにしょうとしている。地域環境に対して，森 林の土畩の影響はきわめて大きい. しかし土壌中で 生じている現象はまだほとんど定量的に判っていな
い. とくに根の現存量, 呼吸量, 分解速度などの データが久落している。メッシュデータが役立つと 期待している.

しかし $100 \mathrm{~m} \times 100 \mathrm{~m}$ の試験林で，流域の環境を 語るにはあまりにも狭い。そこで今後は航空機や人 工衛星の画像デー夕を使った解析とリンクさせたい と考えている.

\section{参考文献}

1 ) 秋山㑆, 菊池多賀夫, 小泉博, 安藤辰夫, 西條好廸, 津 田智, 莫文紅, 車戸憲二, 大塚俊之, 西村格: 冷温帯林 生態系におけるモデル化と予測, 陸上生態系の二酸化炭 素動態の評価と予測・モデリングに関する研究, 環境庁 地球環境研究総合推進費終了研究報告書, p.21-31 (1999)

2 ) 川村健介, 酒井徹, 賈書剛, 秋山㑆, 橋本靖, 和田直 也 : 冷温帯林林床の光環境に及ぼす落葉樹の季節的動態 の影響, システム農学16 (別号 2), 60-61 (2000)

3 ) 吉村登雄, 小宮山桂, 石川敏夫：日射フィルムによる日 射量の簡易測定, 日本エネルギー学会誌 $9,193-204$ (1990)

4 ) 秋山㑆, 酒井徹, 賈書剛, 篠田成郎, 冨久尾歩: フィル ム日射計による群落内光環境計測法の検討, 写真測量と リモートセンシング39 (4), 13-18 (2000)

5 ) 山本晋, 村山昌平, 三枝信子, 近藤裕昭, 西村格: 森林 生態系の二酸化炭素吸収·交換料についての一考察, 資 源と環境 7 (2), 33-41（1998）

6 ) 賈書剛, 秋山㑆, 小泉博, 莫文紅 : 冷温帯落葉樹林の炭 素循環, 7.土壤呼吸速度の時・空間ばらつき, システ 厶農学17 (別号 1) (2001) 